\title{
CARACTERIZAÇÃO PAISAGÍSTICA E DA FREQUÊNCIA DE USUÁRIOS DE DUAS PRAÇAS CENTRAIS DE CARAGUATATUBA/SP
}

\author{
LANDSCAPE AND FREQUENCY OF USERS CHARACTERIZATION IN TWO \\ CENTRAL SQUARES OF CARAGUATATUBA/SP
}

\author{
Marli Aparecida dos Reis Alcantara' ${ }^{1}$; Gisele Herbst Vazquez²
}

\section{RESUMO}

As praças públicas possuem valor estético e recreativo, amenizam a amplitude térmica, fixam poeira, filtram gases, diminuem o nível de ruídos e ventos, absorvem água, abrigam a fauna e promovem a cultura e a cidadania. O objetivo desta pesquisa foi estudar a evolução histórico-cultural e paisagística das praças Dr. Cândido Mota e Dr. Diógenes Ribeiro de Lima em Caraguatatuba/SP, bem como realizar uma análise quali-quantitativa dos elementos arquitetônicos e da vegetação, além da observação dos usuários, com o intuito de subsidiar futuras adequações. Conclui-se que ambas são importantes em termos históricos, principalmente a praça Dr. Cândido Mota por abrigar diversos patrimônios, enquanto que a Dr. Diógenes Ribeiro de Lima oferece mais opções para a prática de exercícios físicos e recreação infantil, sendo também a mais frequentada por adolescentes, e a primeira, por idosos. A qualidade das estruturas físicas de ambas é regular, com estado de conservação inadequado, necessitando de manutenções, não obstante promoverem o lazer dos usuários, principalmente aos finais de semana, visto que durante a semana, o maior movimento é de adultos em passagem à tarde.

Palavras-chave: Áreas públicas; Áreas verdes; Arborização urbana; Sustentabilidade.

\begin{abstract}
Public squares have aesthetic and recreational value, minimize the thermal amplitude, secure the dust, filter gases, reduce the noise level, absorb water, shelter wildlife and promote the culture and the local citizenship. The objective of this research was to study the historical, cultural and landscape evolution of Dr. Cândido Mota and Dr. Diógenes Ribeiro de Lima squares in Caraguatatuba/SP and conduct a qualitative and quantitative analysis of the architectural elements and afforestation, as well as observation of users, in order to support future adaptations. It is concluded that both are important in historical terms, especially Dr. Cândido Mota square for hosting various assets, while Dr. Diógenes Ribeiro de Lima offers more options for physical exercise and children recreation, being the most visited by teens, and the first, by the elderly. The quality of their facilities is average, with inadequate conservation status, requiring maintenance, nevertheless promote leisure for users, especially on weekends, as during the week, most of the movement is adults in transit in the afternoon.
\end{abstract}

Keywords: Public areas; Green areas; Urban forestry; Sustainability.

Recebido em 12.10.2015 e aceito em 03.12.2015

1 Pedagoga, Pós graduada em Psicopedagogia, Gestão Educacional e Coordenação Pedagógica, Mestranda em Ciências Ambientais pela Unicastelo, Fernandópolis/SP. Professora da rede municipal de Caraguatatuba/SP. Email: professora.marli@hotmail.com

2 Engenheira Agrônoma, Dra., Professora do curso de Agronomia e do Mestrado em Ciências Ambientais da Unicastelo, Fernandópolis/SP. Email: gisele-agro@uol.com.br 


\section{INTRODUÇÃO}

Uma cidade sustentável caracteriza-se por atender as necessidades das gerações atuais sem comprometer as futuras. Os espaços construídos, muitas vezes, não conseguem acompanhar a evolução dos tempos, correndo o risco de tornar-se ultrapassado e até mesmo causar danos à saúde. As praças são espaços públicos urbanos livres de edificações que tem a função de promover convivência sadia à população, oferecendo recreação e bem estar num ambiente agradável, além de buscar a democratização do acesso ao esporte e ao lazer, o incentivo a inclusão social e a expressão cultural. Um município ao oferecer à sua população um espaço público qualificado, propicia um ambiente saudável de convivência comunitária.

As políticas públicas desempenham um papel fundamental na adoção de medidas eficientes relacionadas ao meio ambiente e aos espaços urbanos das cidades, espaços como as praças e os parques são opções de lazer e recreação para a comunidade, além da convivência social e benefícios ecológicos (COSTA; SILVA JÚNIOR; RANGEL, 2010).

Com o crescimento das cidades e a deterioração dos espaços públicos, as pessoas se distanciaram, não havendo mais tempo para o bate-papo e a contemplação da natureza. $O$ fato é que os tempos mudaram e com eles vieram novos hábitos e costumes deixando a praça de ser um espaço prioritário de recreação e convivência. Em muitas das vezes, é o seu mal estado de conservação que acarreta a subutilização destes espaços. Uma praça suja e abandonada afasta as pessoas e cria um círculo vicioso de degradação, já que são os próprios frequentadores os responsáveis por cuidar ou deteriorar estas áreas.

As praças não podem ser colocadas em segundo plano pelo poder público e pela comunidade, ao contrário, devem ser percebidas como necessárias e importantes na qualidade de vida de seus moradores. Estas, além de ser um espaço de valor estético e recreativo, amenizam a amplitude térmica nos centros urbanos, fixam a poeira atmosférica, filtram gases poluentes, diminuem o nível de ruídos, reduzem a intensidade dos ventos, absorvem água, melhoram a umidade, abrigam a fauna local e promovem a cultura e a cidadania por meio de eventos e atividades cívicas (SOUZA; AMORIM, 2013).

Para que uma praça seja agradável para quem frequenta é necessário que esse meio físico atenda às necessidades dos usuários, para isso são considerados fatores positivos como arborização, aparelhos para atividade física e de recreação, banheiros e bebedouros, a acessibilidade, a conservação e a limpeza, a segurança, entre outros; e negativos, como a sujeira, o desconforto, a degradação, a inadequação de usos e a falta de manutenção, principalmente.

Caraguatatuba/SP é a primeira cidade da região pela Rodovia dos Tamoios, a SP99, saindo de São Paulo, sendo o portal de entrada para as demais praias do litoral norte. 
Como cidade turística, é muito frequentada durante todo o ano, recebendo turistas de veraneio, e também, aqueles que vêm apenas para passar o dia atraído pelas suas belezas.

O objetivo desta pesquisa foi estudar a evolução histórico-cultural e paisagística das praças Dr. Cândido Mota e Dr. Diógenes Ribeiro de Lima da região central de Caraguatatuba/SP, bem como realizar uma análise quali-quantitativa dos elementos arquitetônicos e da vegetação, além da observação dos usuários, com o intuito de compreender o desempenho desses espaços e subsidiar futuras adequações municipais para melhor atender a população.

\section{MATERIAL E MÉTODOS}

\section{Caracterização da cidade de Caraguatatuba/SP}

A cidade de Caraguatatuba (Figura 1) está localizada na latitude de $23^{\circ} 37^{\prime} 13^{\prime \prime} \mathrm{S}$ e longitude de $45^{\circ}$ 24' 47" W, com uma altitude de 2 metros, possuindo uma área de 485,087 $\mathrm{km}^{2}$. Segundo a classificação climática de Köppen, o clima é Af, caracterizado como tropical chuvoso, sem estação seca definida e com precipitação média do mês mais seco superior a $60 \mathrm{~mm}$ e média anual de $1760 \mathrm{~mm}$ (ROLIM et al., 2007).

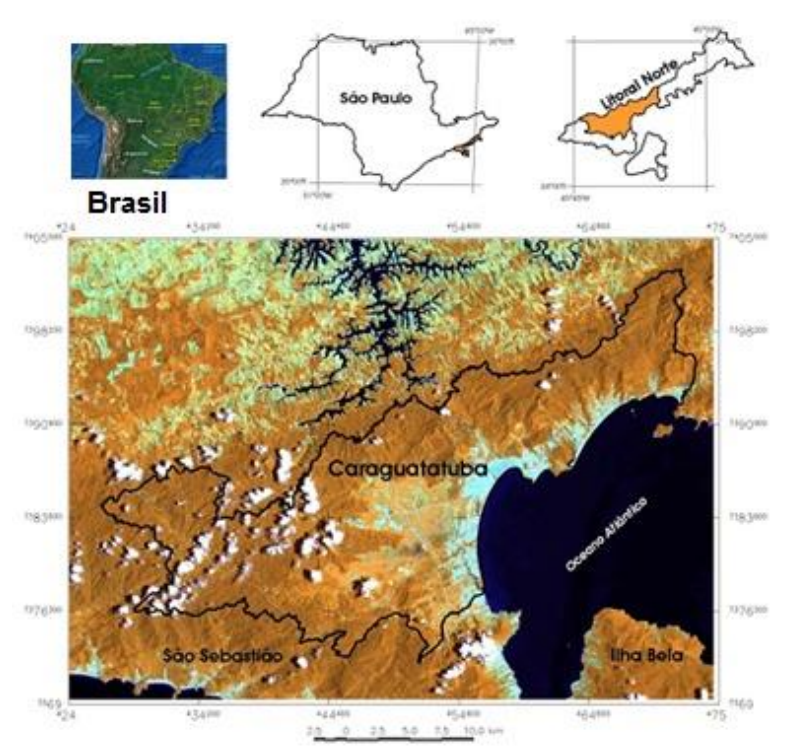

Figura 1. Localização do município de Caraguatatuba/SP

Figure 1. Location of municipality of Caraguatatuba/SP

De acordo com o Instituto Brasileiro de Geografia e Estatística - IBGE, segundo as estimativas de $1^{\circ}$ de julho de 2014 publicada no Diário Oficial da União, Caraguatatuba possuía em 2014 uma população estimada de 113.317 (IBGE, 2014). 


\section{Localização das praças e execução da pesquisa}

O trabalho foi realizado nas Praças Dr. Cândido Mota e Dr. Diógenes Ribeiro de Lima, que são as mais antigas de Caraguatatuba/SP e possuem elevado valor histórico, localizadas, respectivamente, entre as ruas Altino Arantes, São Benedito, Dr. Paul Harris e Sebastião Mariano Nepomuceno e entre as ruas Ivan Micheletto Rossi, Major Ayres, Santa Cruz e a avenida Dr. Arthur da Costa Filho (Figura 2).

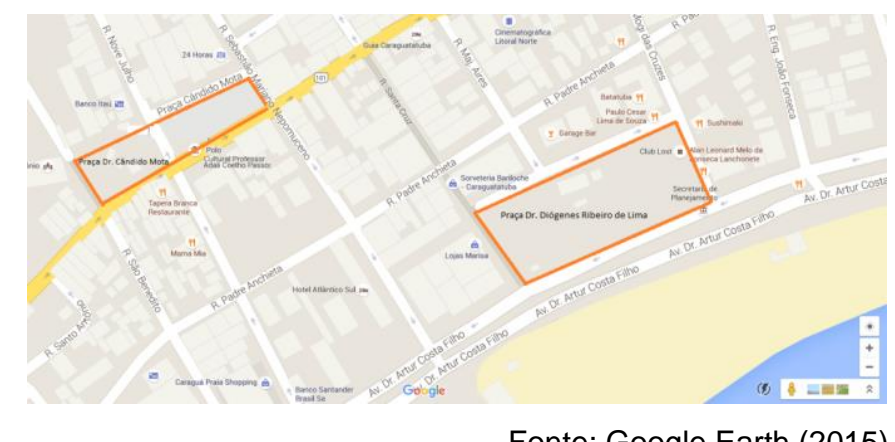

Fonte: Google Earth (2015)

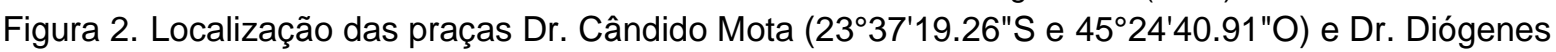

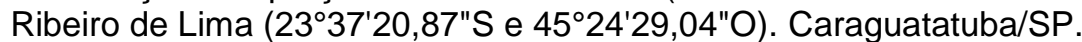

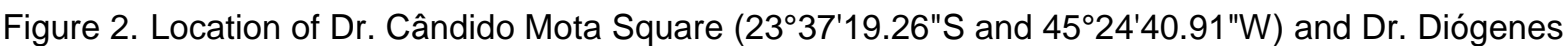

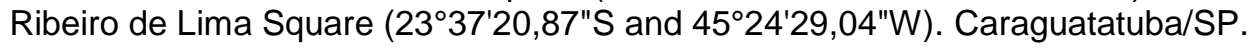

Foi realizado um levantamento da evolução histórico-cultural, uma análise qualiquantitativa dos elementos arquitetônicos, a caracterização dos usuários e a determinação das espécies vegetais presentes nas praças.

Para o levantamento histórico buscou-se o Arquivo Público e Histórico de Caraguatatuba do Polo Cultural Adaly Coelho Passos, a Fundação Cultural de Caraguatatuba (FUNDACC), a Secretaria de Turismo e a Prefeitura Municipal, além das bibliotecas municipais e meio eletrônico, no período de março de 2014 a julho de 2015.

Para a realização do levantamento quali-quantitativo dos elementos arquitetônicos das praças foram realizadas visitas in loco em janeiro de 2015 com a aplicação de um roteiro de observação baseado na metodologia proposta por De Angelis, Castro e De Angelis (2004).

Para a análise quantitativa foi feito um levantamento quanto à presença ou ausência dos elementos arquitetônicos e para a qualitativa foi previamente estabelecido e utilizado uma escala numérica de 0 a 4 e, em seguida, atribuídos conceitos: péssimo (notas de 0 a 0,5), ruim (notas de 0,5 a 1,5), regular (notas de 1,5 a 2,5), bom (notas de 2,5 a 3,5) e ótimo (notas de 3,5 a 4,0). Assim, cada equipamento foi avaliado quanto a vários parâmetros, como, condição de conservação, disponibilidade para uso, qualidade do material utilizado, manutenção, conforto, funcionalidade, segurança, entre outros, que atendidos ou não, geraram uma nota (Tabela 1 ). 
Tabela 1. Avaliação qualitativa dos elementos arquitetônicos, notas e conceitos de acordo com o padrão de desempenho do equipamento

Table1. Qualitative assessment of architectural elements, notes and concepts according to the standard of performance of the equipment

\begin{tabular}{ccl}
\hline NOTA & CONCEITO & \multicolumn{1}{c}{ PADRÃO DE DESEMPENHO } \\
\hline $0-0,5$ & PÉSSIMO & Insuficiente/não atende a nenhum critério avaliado com qualidade \\
$0,5-1,5$ & RUIM & Pouco suficiente/atende somente 1 ou 2 itens avaliados \\
$1,5-2,5$ & REGULAR & Parcialmente atendido/atende menos da metade dos critérios avaliados \\
$2,5-3,5$ & BOM & Suficientemente atendido/atende a maioria dos critérios avaliados \\
$3,5-4,0$ & ÓTIMO & Plenamente atendido/atende todos os critérios avaliados \\
\hline
\end{tabular}

Equipamentos e seus parâmetros avaliados:

- Bancos: quantidade suficiente, material, conservação, localização (sombra/sol);

- Iluminação alta/iluminação baixa: localização, conservação, segurança, disposição da iluminação nos acessos e nas áreas de circulação, otimização dos pontos de luz em função da copa das árvores, adequação à função socioambiental do espaço, considerando a paisagem, a segurança e o impacto sobre a vegetação arbórea;

- Lixeiras: tipo, adequação da quantidade ao número de usuários, localização e distanciamento, funcionalidade, material empregado, conservação e estética;

- Sanitários: quantidade, disponibilidade de uso, condições de uso e conservação;

- Telefone público: disposição, disponibilidade, acessibilidade e conservação;

- Bebedouros: tipo, quantidade, limpeza e higiene, condições de uso, conservação e acessibilidade;

- Piso: material empregado; funcionalidade e segurança; conservação, estética, durabilidade, facilidade para manutenção, permeabilidade e acessibilidade;

- Traçado dos caminhos: funcionalidade, largura, manutenção, desenho e acessibilidade;

- Coreto/esculturas: valor histórico, funcionalidade, finalidade, conservação, design, disponibilidade de uso, se compatível com o desenho da praça;

- Pergolados: material, disposição, conservação e estética;

- Monumento: significância da obra de arte no aspecto histórico, conservação, inserção no conjunto da praça, identificação;

- Espelho d'água/chafariz: em funcionamento: se inserido ou não no contexto da praça; conservação e manutenção da água e da estrutura;

- Estacionamento: localização, quantidade de vagas (atendimento às necessidades dos usuários), conservação, segurança e sombreamento;

- Ponto de ônibus/ponto de táxi: se na praça, próximo ou distante de, presença ou não de abrigo, conservação e atendimento às necessidade dos horários dos usuários;

- Quadra esportiva: quantidade, conservação, material empregado, disposição, cercada ou não, iluminação, acessibilidade e placas de orientação aos usuários; 
- Equipamentos para exercícios físicos: tipo e quantidade, acesso, material empregado, conservação, adequação dos aparelhos as normas específicas e atendimento a todas as faixas etárias, acessibilidade, disposição de informações sobre sua forma de uso e segurança;

- Estruturas para terceira idade: conservação, material, adequação dos aparelhos as normas específicas e atendimento a faixa etária, acessibilidade, disposição de informações sobre sua forma de uso e segurança;

- Equipamentos para recreação infantil: material empregado (resistência, de fácil limpeza e pouca manutenção), conservação, adequação dos aparelhos as normas específicas e atendimento a faixa etária, área cercada, segurança e acessibilidade;

- Banca de revista: localização, estrutura, material de construção, design, estética e conservação, atendimento às necessidades dos horários dos usuários;

- Quiosque de alimentação ou similar: localização, limpeza, estrutura, design, estética, atendimento às necessidades dos horários dos usuários;

- Vegetação: quantidade, disposição, conservação e contribuição ambiental e estética;

- Paisagismo: conservação, manutenção e contribuição estética, social e ambiental;

- Localização: atendimento às necessidades dos usuários;

- Conservação/limpeza: frequência de manutenção e qualidade do serviço;

- Segurança: quantidade e frequência de policiais.

A caracterização dos usuários foi realizada por meio de observação sem a abordagem direta durante os meses de fevereiro e março de 2015, de segunda a domingo, com exceção dos feriados, por duas horas diárias nos períodos matutino (das 6:30 às 7:30 h) e vespertino (das 17:00 às 18:00 h), nos quais foram observados o perfil dos frequentadores e as atividades desenvolvidas (lazer ou passagem).

Foi considerado como atividade de lazer o indivíduo que permaneceu no mínimo trinta minutos na praça, realizando qualquer atividade que garantisse a sua permanência. $O$ público foi contabilizado de acordo com a sua faixa etária aparente e por uma única pessoa, de maneira a evitar o confronto de critérios, ou seja, criança (de 0 a 12 anos), adolescente (de 13 a 20 anos), adulto (de 21 a 60 anos) e idoso (acima de 61 anos).

Por fim, foi realizado um levantamento das espécies vegetais arbóreas, arbustivas e palmáceas com dois metros ou mais de altura e calculada a sua frequência relativa e procedência (se nativa ou exótica). 


\section{RESULTADOS E DISCUSSÃO}

\section{Análise da praça Dr. Cândido Mota}

Os documentos relativos à fundação da cidade de Caraguatatuba, atos do Executivo e do Legislativo Municipal referem-se à Praça Dr. Cândido Mota como Praça da Capela de Santo Antônio ou Praça da Igreja Matriz, indicando que este era o ponto principal do município. Com o tempo, ao seu redor estabeleceram-se residências, casas de comércio, a câmara municipal e outros logradouros públicos que caracterizavam o espaço urbano. Integrando a paisagem urbana da antiga praça estava o prédio da Escola Pública Feminina que funcionou até a década de 30 e o Grupo Escolar Adaly Coelho Passos, que inaugurado na década de 40, veio a valorizar o espaço público dando início a escolarização municipal.

A praça Dr. Cândido Mota, um dos patrimônios históricos do município, possui uma área $7.005 \mathrm{~m}^{2}$, é arborizada e tranquila, sendo ótima opção para passeios em família. Acompanhar atividades musicais como a banda municipal Carlos Gomes, ouvir chorinho, MPB e bossa nova é um dos atrativos dos moradores e turistas nos fins de semana e feriados. Outros atrativos também chamam a atenção, como a Igreja Matriz de Santo Antônio, a Torneira ou Obelisco, o Relógio do Sol, o Coreto e a Fonte Luminosa, sendo todos patrimônios municipais protegidos pela Lei no 1344/2006 (CARAGUATATUBA, 2006).

Quanto ao levantamento quantitativo (Tabela 2), os bancos desta praça, num total de 18, atendem parcialmente as necessidades dos usuários, visto que em diversos dias durante a realização deste estudo todos estavam ocupados; mas ao se considerar o item qualitativo (Tabela 2), os mesmos são ruins, pois apresentam rachaduras e deslize de terra do jardim que se encontra atrás do banco (Figura 3). A estrutura é de cimento e sua localização é adequada, já que envolve tanto áreas ensolaradas, quanto sombreadas. Segundo Demattê (1999), os bancos de uma praça devem ser discretos, confortáveis, duráveis e de fácil limpeza e estar localizados tanto no sol quanto na sombra; isolados ou em grupos e voltados para o lado interno e externo. Já de acordo com De Angelis et al. (2005), uma praça não necessariamente deve ter bancos, porém, dotar esses espaços com tal equipamento é interessante, sobretudo para uso de pessoas da terceira idade e por ser um local de encontro e socialização.

O entorno da praça é iluminado por 35 postes com fiação de alta tensão, as estruturas de ferro suportam 3 pontos de iluminação e encontram-se em boas condições. As lixeiras não estão adequadas às necessidades dos usuários quanto ao número existente, ou seja, apenas 8 , são pequenas e nem sempre estão com sacos plásticos de lixo, ocasionando 
o escorrimento de chorume, além de possuírem propagandas em suas laterais, o que polui o visual, contrariando o preconizado por Demattê (1999).

Tabela 2. Levantamento quantitativo e qualitativo dos elementos arquitetônicos da praça Dr. Cândido Mota. Caraguatatuba/SP, 2015

Table 2. Quantitative and qualitative survey of the architectural elements of Dr. Cândido Mota square. Caraguatatuba/SP, 2015

\begin{tabular}{|c|c|c|c|}
\hline \multicolumn{4}{|c|}{ PRAÇA DR. CÂNDIDO MOTA } \\
\hline \multicolumn{4}{|c|}{ FORMA GEOMÉTRICA:（）QUADRANGULAR（）CIRCULAR } \\
\hline $\begin{array}{c}\text { Quantitativo } \\
\text { Equipamento/Estrutura }\end{array}$ & Quant & $\begin{array}{c}\text { Qualitativo } \\
\text { Equipamento/Estrutura }\end{array}$ & Conceito \\
\hline Bancos: quantidade & 18 & Bancos & Ruim \\
\hline Iluminação: $(X)$ alta ( ) baixa & 35 & Iluminação & Bom \\
\hline Lixeiras: quantidade & 08 & Lixeiras & Ruim \\
\hline Sanitários & 00 & Sanitários & - \\
\hline Telefone público & 04 & Telefone público & Ruim \\
\hline Bebedouros & 00 & Bebedouros & - \\
\hline Caminhos & 12 & Piso & Regular \\
\hline Coreto / escultura / pergolado & 01 & Traçado dos caminhos & Regular \\
\hline Obra de arte: $(X)$ monumento ( ) estátua & 02 & Palco / coreto / esculturas & Regular \\
\hline Espelho d'água / chafariz & 01 & Pergolado & - \\
\hline Estacionamento & 00 & Monumento & Bom \\
\hline Ponto de ônibus & 00 & Espelho d'água / chafariz & Bom \\
\hline Ponto de taxi & 01 & Estacionamento & - \\
\hline Quadra esportiva & 00 & Ponto de ônibus & - \\
\hline Equipamentos de exercícios físicos & 00 & Ponto de taxi & Regular \\
\hline Estrutura para terceira idade & 00 & Quadra esportiva & \\
\hline Equipamentos recreação infantil & 00 & Equipamentos de exercícios físicos & - \\
\hline Banca de revista & 01 & Estrutura para terceira idade & - \\
\hline Quiosque de alimentação ou similar & 03 & Parque infantil & - \\
\hline Identificação & 01 & Banca de revista & Regular \\
\hline Edificação institucional & 00 & Quiosque de alimentação ou similar & Regular \\
\hline Templo religioso & 01 & Vegetação & Regular \\
\hline & & Paisagismo & Regular \\
\hline & & Localização & Ótimo \\
\hline & & Conservação / limpeza & Regular \\
\hline & & Segurança & Bom \\
\hline
\end{tabular}

Nota: Quant = quantidade
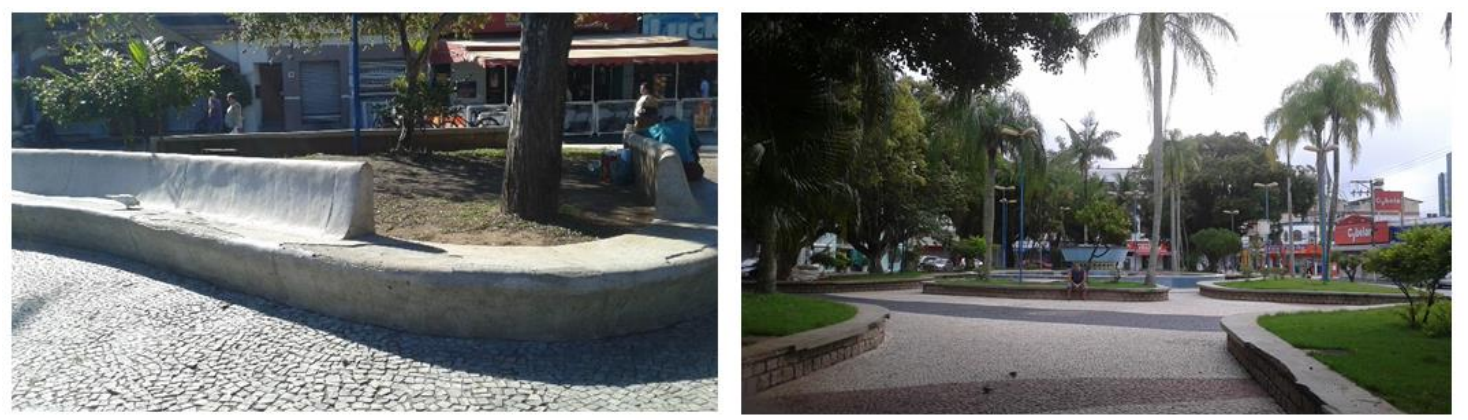

Figura 3. Bancos da Praça Dr. Cândido Mota. Caraguatatuba/SP, 2015

Figure 3. Benches of Dr. Cândido Mota Square. Caraguatatuba/SP, 2015

Há um ponto de taxi que atende a população no período das 6 às 24h, sendo referência para quem precisa do serviço na região central da cidade. A praça é pavimentada com desenhos em pedra, estando em boas condições de uso, as calçadas são rebaixadas em 
vários pontos facilitando a acessibilidade das diferentes faixas etárias e portadores de deficiências, porém não há piso tátil. Não há sanitários, bebedouros, quadra esportiva, pergolado, ponto de ônibus, equipamentos para a prática de exercícios físicos para a terceira idade e recreação infantil, palco ou quiosque de alimentação. Os telefones públicos existentes são poucos e, em muitas das vezes, sua estrutura é utilizada para trancar as bicicletas dos usuários, tornando-se ainda mais difícil o seu uso.

A praça, em nível geral, encontra-se limpa, sendo frequente a presença de funcionários realizando esse serviço. Quanto à poda de árvores, esta é realizada regularmente. As árvores estão posicionadas em diferentes localizações, proporcionando espaços na sombra e outros ao sol.

Como regulador da temperatura urbana, a vegetação é um importante componente, pois os processos biológicos fazem com que a radiação solar seja absorvida com facilidade, e assim as temperaturas tornam-se mais amenas. Como locais públicos de lazer, as praças devem proporcionar condições de bem-estar para que os usuários tenham maior qualidade nas atividades desenvolvidas, condições essas proporcionadas pela presença de vegetação (LOBODA; DE ANGELIS, 2009).

No espaço urbano, as praças e parques são elementos importantes, pois constituem áreas específicas nas cidades, que remetem à conservação da natureza, proporcionando lazer ativo e contemplativo ao usuário, instigando-o a desenvolver diferentes olhares sobre o meio ambiente colaborando com o desenvolvimento do processo de sensibilização, conscientização e criticidade (GOMES et al., 2012).

Há uma boa frequência de policiais militares no local, assim como dos agentes de trânsito, possibilitando maior segurança aos usuários. Há uma única banca de jornal e revistas, que está localizada bem no centro da praça, atendendo de forma adequada às necessidades dos usuários. As placas de identificação da praça ficam em locais acessíveis e de fácil visualização, facilitando seu reconhecimento. Já o coreto, embora bem localizado e de apresentar boa estrutura, tem servido de abrigo para os moradores de rua da região. Existe também a presença de muitos pombos no local, visto que há sorveteiros, pipoqueiros e vendedores ambulantes, além de ser comum ver pessoas alimentando esses pássaros.

Durante os 45 dias de desenvolvimento da pesquisa de observação foram contabilizados na Praça Dr. Cândido Mota um total de 29.606 pessoas, sendo 10.929 no período matutino (243 usuários/h ou 36,9\%) e 18.677 no vespertino (415 usuários/h ou 63,1\%) (Tabela 3).

No que se refere ao tipo de atividade, pode-se observar que a praça foi mais utilizada como passagem pelos usuários, principalmente no período vespertino, num total de 13.505 pessoas (300 usuários/h), enquanto no período da manhã transitaram 7.821 pessoas (174 
usuários $/ h)$. Já quando se contabiliza a porcentagem desta atividade nos dois períodos do dia, verifica-se que é praticamente o mesmo, ou seja, cerca de $72 \%$ das pessoas estão de passagem pela praça (Tabela 3 ).

Tabela 3. Total de usuários e por hora da Praça Dr. Cândido Mota nos períodos matutino e vespertino, de acordo com o tipo de atividade.Caraguatatuba/SP, 2015

Table 3. Total users and average per hour of Dr. Cândido Mota Square in the morning and afternoon periods, according to the type of activity. Caraguatatuba/SP, 2015

\begin{tabular}{|c|c|c|c|c|}
\hline Tipo de atividade & $\begin{array}{c}\text { Total } \\
\text { (45 dias) } \\
\text { Matutino } \\
\end{array}$ & $\begin{array}{c}\text { Total } \\
\text { (45 dias) } \\
\text { vespertino }\end{array}$ & $\begin{array}{c}\text { Média } \\
\text { pessoas/hora } \\
\text { matutino }\end{array}$ & $\begin{array}{c}\text { Média } \\
\text { pessoas/hora } \\
\text { vespertino }\end{array}$ \\
\hline Lazer & 3.108 & 5.172 & $69(28,4 \%)$ & $115(27,7 \%)$ \\
\hline Passagem & 7.821 & 13.505 & $174(71,6 \%)$ & $300(72,3 \%)$ \\
\hline Geral & 10.929 & 18.677 & $243(36,9 \%)$ & $415(63,1 \%)$ \\
\hline
\end{tabular}

O indivíduo que mais transitou pela praça foi o adulto, nos dois períodos, $46,0 \%$ no matutino e $42,7 \%$ no vespertino, os quais provavelmente estavam se dirigindo para o trabalho pela manhã ou saindo deste à tarde (Tabela 4).

Da mesma forma, foi observado um grande número de adolescentes (24,2\% pela manhã e $25,0 \%$ à tarde), que se dirigiam as cinco escolas próximas à praça (Tabela 4).

Quanto ao lazer em cada faixa etária, as crianças (17,5\%) e os adolescentes $(27,3 \%)$ fizeram maior uso da praça no período vespertino, enquanto que os adultos $(39,6 \%)$ e os idosos $(30,3 \%)$ frequentam o local mais pela manhã (Tabela 4$)$.

Tabela 4. Usuários da Praça Dr. Cândido Mota de acordo com o tipo de atividade e período do dia. Caraguatatuba/SP, 2015

Table 4. Users of Dr. Cândido Mota Square according to the type of activity and period of the day. Caraguatatuba/SP, 2015

\begin{tabular}{|c|c|c|c|c|}
\hline \multirow{2}{*}{ Público alvo } & \multicolumn{2}{|c|}{ Passagem (média pessoas/h e \%) } & \multicolumn{2}{|c|}{ Lazer (média pessoas/h e \%) } \\
\hline & Matutino & Vespertino & Matutino & Vespertino \\
\hline Criança & $13(7,6 \%)$ & $43(14,3 \%)$ & $4(5,5 \%)$ & $20(17,5 \%)$ \\
\hline Adolescente & $42(24,2 \%)$ & $75(25,0 \%)$ & $17(24,6 \%)$ & $31(27,3 \%)$ \\
\hline Adulto & $80(46,0 \%)$ & $128(42,7 \%)$ & $27(39,6 \%)$ & $35(31,5 \%)$ \\
\hline Idoso & $39(22,5 \%)$ & $54(18,0 \%)$ & $21(30,3 \%)$ & $29(26,3 \%)$ \\
\hline
\end{tabular}

Quanto à frequência semanal, em praticamente todos os dias da semana, o número de pessoas que passam pela praça supera o que está a lazer, nos dois períodos do dia e para todas as faixas etárias (Tabela 5). Sexta-feira, sábado e domingo são os dias com maior número de frequentadores na praça nos dois períodos, sendo o domingo o dia da semana com maior número de usuários no período matutino (420 pessoas/h) e no vespertino, no sábado à tarde (484 pessoas/h), havendo praticamente o mesmo número de pessoas no 
domingo à tarde (483 pessoas/h). Na segunda-feira pela manhã a praça recebe o menor público (166 pessoas/h) e a tarde isso ocorre às quartas-feiras (324 pessoas/h).

Em termos numéricos (Tabela 5), quanto ao lazer, as crianças frequentam a praça principalmente no sábado e no domingo à tarde, já os adolescentes no domingo a tarde e os adultos e os idosos no domingo pela manhã e a tarde. Já em termos de usuários de passagem, as crianças trafegam pela praça mais na sexta e na segunda-feira, os adolescentes no sábado e na segunda-feira, os adultos no domingo e no sábado e os idosos na terça-feira, todos no período vespertino.

Tabela 5. Usuários por hora em cada dia da semana de acordo com a atividade (lazer ou passagem) e período do dia (matutino e vespertino) na Praça Dr. Cândido Mota. Caraguatatuba/SP, 2015

Table 5. Users per hour in each day of the week according to the activity (recreation or passage) and period of the day (morning and afternoon) in Dr. Cândido Mota Square. Caraguatatuba/SP, 2015

\begin{tabular}{|c|c|c|c|c|c|c|c|c|c|c|c|c|c|c|c|c|c|c|}
\hline & \multicolumn{4}{|c|}{ Criança } & \multicolumn{4}{|c|}{ Adolescente } & \multicolumn{4}{|c|}{ Adulto } & \multicolumn{4}{|c|}{ Idoso } & \multicolumn{2}{|c|}{ Total } \\
\hline & \multicolumn{2}{|c|}{$M$} & \multicolumn{2}{|c|}{ V } & \multicolumn{2}{|c|}{$\mathrm{M}$} & \multicolumn{2}{|c|}{$\mathrm{V}$} & \multicolumn{2}{|c|}{$M$} & \multicolumn{2}{|c|}{ V } & \multicolumn{2}{|c|}{$\mathrm{M}$} & \multicolumn{2}{|c|}{ V } & \multirow{2}{*}{ M } & \multirow{2}{*}{ V } \\
\hline & $\mathrm{L}$ & $\mathrm{P}$ & $\mathrm{L}$ & $\mathrm{P}$ & $\mathrm{L}$ & $\mathrm{P}$ & $\mathrm{L}$ & $P$ & $\mathrm{~L}$ & $\mathrm{P}$ & $\mathrm{L}$ & $P$ & $\mathrm{~L}$ & $\mathrm{P}$ & $\mathrm{L}$ & $P$ & & \\
\hline D & 11 & 32 & 35 & 32 & 29 & 59 & 47 & 58 & 61 & 122 & 61 & 145 & 44 & 62 & 43 & 62 & 420 & 483 \\
\hline $2^{\underline{a}}$ & 1 & 5 & 14 & 50 & 6 & 31 & 17 & 95 & 13 & 79 & 19 & 123 & 8 & 24 & 32 & 52 & 166 & 402 \\
\hline $3^{a}$ & 1 & 7 & 13 & 38 & 9 & 31 & 22 & 63 & 15 & 84 & 26 & 128 & 12 & 34 & 20 & 64 & 194 & 375 \\
\hline $4^{\mathrm{a}}$ & 2 & 15 & 14 & 35 & 14 & 36 & 26 & 56 & 18 & 61 & 20 & 111 & 14 & 43 & 21 & 42 & 203 & 324 \\
\hline $5^{\underline{a}}$ & 1 & 7 & 17 & 48 & 13 & 30 & 24 & 60 & 23 & 61 & 23 & 113 & 20 & 34 & 26 & 52 & 189 & 363 \\
\hline $6^{\underline{a}}$ & 2 & 15 & 21 & 51 & 20 & 59 & 38 & 77 & 29 & 75 & 50 & 130 & 26 & 34 & 32 & 47 & 259 & 445 \\
\hline S & 10 & 13 & 25 & 41 & 28 & 50 & 41 & 110 & 33 & 61 & 49 & 137 & 24 & 41 & 32 & 49 & 257 & 484 \\
\hline
\end{tabular}

Nota: $\mathrm{M}=$ matutino, $\mathrm{V}=$ vespertino, $\mathrm{L}=$ lazer, $\mathrm{P}=$ passagem, $\mathrm{D}=$ domingo, $\mathrm{S}=$ sábado

Quanto à porcentagem em cada categoria e em cada dia da semana, do total de pessoas que frequentam a praça (lazer e passagem) no domingo pela manhã em atividade de lazer existem $3 \%$ de crianças, $7 \%$ de adolescentes, $15 \%$ de adultos e $11 \%$ de idosos, já no período vespertino são $7 \%$ de crianças, $10 \%$ de adolescentes, $13 \%$ de adultos e $9 \%$ de idosos. No sábado pela manhã são $4 \%$ de crianças, $11 \%$ de adolescentes, $13 \%$ de adultos e $9 \%$ de idosos e a tarde, $5 \%$ de crianças, $8 \%$ de adolescentes, $10 \%$ de adultos e $7 \%$ de idosos (Tabela 6).

Tabela 6. Porcentagem de usuários por hora em cada dia da semana de acordo com a atividade (lazer ou passagem) na Praça Dr. Cândido Mota. Caraguatatuba/SP, 2015

Table 6. Percentage of users per hour in each day of the week according to the activity (recreation or passage) in Dr. Cândido Mota Square. Caraguatatuba/SP, 2015

\begin{tabular}{|c|c|c|c|c|c|c|c|c|c|c|c|c|c|c|c|c|c|c|}
\hline & \multicolumn{4}{|c|}{ Criança \% } & \multicolumn{4}{|c|}{ Adolescente \% } & \multicolumn{4}{|c|}{ Adulto \% } & \multicolumn{4}{|c|}{ Idoso \% } & \multicolumn{2}{|c|}{ Total \% } \\
\hline & \multicolumn{2}{|c|}{$\mathrm{M}$} & \multicolumn{2}{|c|}{$\mathrm{V}$} & \multicolumn{2}{|c|}{$\mathrm{M}$} & \multicolumn{2}{|c|}{$\mathrm{V}$} & \multicolumn{2}{|c|}{$\mathrm{M}$} & \multicolumn{2}{|c|}{$\mathrm{V}$} & \multicolumn{2}{|c|}{$\mathrm{M}$} & \multicolumn{2}{|c|}{$\mathrm{V}$} & \multirow{2}{*}{$L$} & \multirow{2}{*}{$P$} \\
\hline & $\mathrm{L}$ & $\mathrm{P}$ & $\mathrm{L}$ & $\mathrm{P}$ & $\mathrm{L}$ & $\mathrm{P}$ & $\mathrm{L}$ & $\mathrm{P}$ & $\mathrm{L}$ & $\mathrm{P}$ & $\mathrm{L}$ & $\mathrm{P}$ & $L$ & $\mathrm{P}$ & $\mathrm{L}$ & $\mathrm{P}$ & & \\
\hline D & 3 & 8 & 7 & 7 & 7 & 14 & 10 & 12 & 15 & 29 & 13 & 30 & 11 & 15 & 9 & 13 & 37 & 63 \\
\hline $2^{a}$ & 0 & 3 & 3 & 13 & 3 & 19 & 4 & 24 & 8 & 47 & 5 & 31 & 5 & 14 & 8 & 13 & 18 & 82 \\
\hline $3^{\underline{a}}$ & 1 & 4 & 3 & 10 & 5 & 16 & 6 & 17 & 8 & 44 & 7 & 34 & 6 & 18 & 5 & 17 & 21 & 79 \\
\hline $4^{\underline{a}}$ & 1 & 8 & 4 & 11 & 7 & 17 & 8 & 17 & 9 & 30 & 6 & 34 & 7 & 21 & 6 & 13 & 24 & 76 \\
\hline $5^{\underline{a}}$ & 1 & 4 & 5 & 13 & 7 & 16 & 7 & 16 & 12 & 32 & 6 & 31 & 11 & 18 & 7 & 14 & 28 & 72 \\
\hline $6^{-a}$ & 1 & 6 & 5 & 11 & 8 & 23 & 9 & 17 & 11 & 29 & 11 & 29 & 10 & 13 & 7 & 11 & 30 & 70 \\
\hline$S$ & 4 & 5 & 5 & 8 & 11 & 19 & 8 & 23 & 13 & 24 & 10 & 28 & 9 & 16 & 7 & 10 & 33 & 67 \\
\hline
\end{tabular}

Nota: $\mathrm{M}=$ matutino, $\mathrm{V}=$ vespertino, $\mathrm{L}=$ lazer, $\mathrm{P}=$ passagem, $\mathrm{D}=$ domingo, $\mathrm{S}=$ sábado 
Não obstante o número de usuários que transitam pela praça ser bem maior do que os que a utilizam para lazer, verifica-se também que a porcentagem de pessoas que frequentam a praça Dr. Cândido Mota para atividades de lazer aumenta de forma linear do início da semana (segunda-feira) até no domingo, quando o maior público é encontrado, chegando até a dobrar em termos porcentuais (Figura 4).

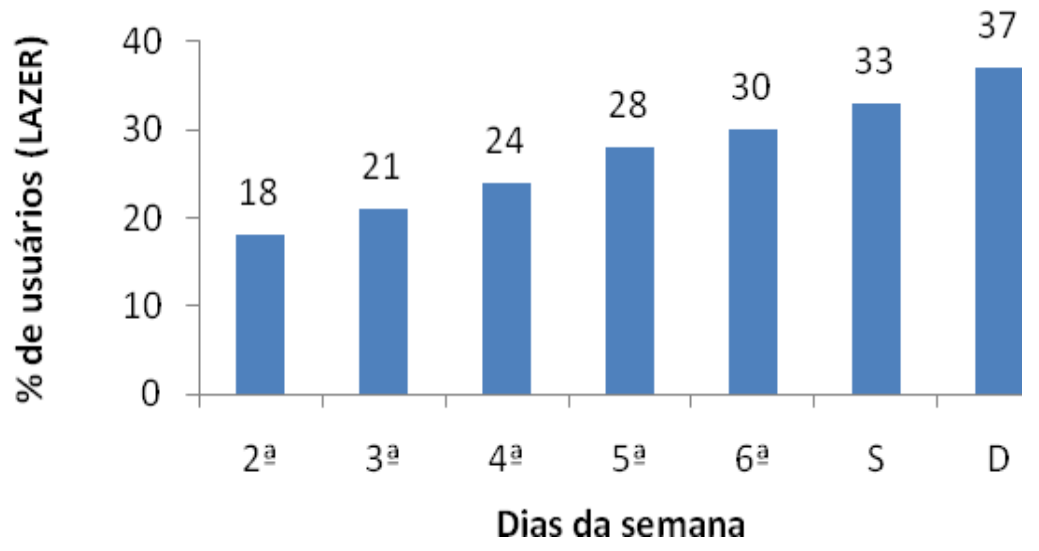

Figura 4. Usuários em atividade de lazer (\%) em cada dia da semana na Praça Dr. Cândido Mota. Caraguatatuba/SP, 2015

Figure 4. Users in leisure activity (\%) in each weekday at Dr. Cândido Mota Square. Caraguatatuba/ SP, 2015

Além do lazer e a recreação proporcionados pelo espaço das praças, elas desempenham outras funções, como a ecológica constatada pela presença de solo permeável para infiltração da água da chuva, a vegetação e a presença de animais, que melhoram a qualidade do ar e do clima, e ligada à diversificação da paisagem, a função estética que, além do embelezamento proporciona um ambiente mais harmonioso aos usuários (DOURADO; SILVA, 2005).

No levantamento das espécies vegetais arbóreas presentes na Praça Dr. Cândido Mota foram encontradas 25 espécies com mais de dois metros, num total de 89 plantas (15 arbóreas, 8 palmáceas e 2 arbustos) (Tabela 7). Predominam as espécies nativas (56,6\%), sendo a mais encontrada, com 12 exemplares (13,5\%), a Syagrus romanzoffiana Glassman, conhecida como palmeira-jerivá. 
Tabela 7. Espécies vegetais encontradas na Praça Dr. Cândido Mota. Caraguatatuba, 2015

Table 7. Plants species found in Square Dr. Cândido Mota. Caraguatatuba, 2015

\begin{tabular}{|c|c|c|c|c|c|c|}
\hline Grupo & Nome científico & Nome comum & Família & Quantidade & $\begin{array}{c}\text { Frequência } \\
\%\end{array}$ & Espécie \\
\hline AR & $\begin{array}{c}\text { Anadenanthera } \\
\text { colubrina (Vell.) } \\
\text { Brenan }\end{array}$ & $\begin{array}{l}\text { Angico-branco ou } \\
\text { Cambuí-angico }\end{array}$ & Fabaceae & 1 & 1,1 & Nativa \\
\hline AR & $\begin{array}{l}\text { Anadenanthera } \\
\text { peregrina (L.) Speg }\end{array}$ & Angico-vermelho & Fabaceae & 2 & 2,2 & Nativa \\
\hline PA & $\begin{array}{l}\text { Archontophoenix } \\
\text { cunninghamiana H. } \\
\text { Wendl. \& Drude }\end{array}$ & Palmeira-seafortia & Palmaceae & 2 & 2,2 & Exótica \\
\hline PA & $\begin{array}{c}\text { Attalea oleifera Barb. } \\
\text { Rodr. }\end{array}$ & Indaiá & Palmaceae & 5 & 5,6 & Nativa \\
\hline$A B$ & $\begin{array}{c}\text { Bougainvillea glabra } \\
\text { Choisy var. graciliflora } \\
\text { Heimerl }\end{array}$ & Primavera & Nyctaginaceae & 2 & 2,2 & Nativa \\
\hline PA & Cocos nucifera L. & Coco-da-baía & Palmaceae & 2 & 2,2 & Exótica \\
\hline$A B$ & $\begin{array}{c}\text { Cordyline terminalis } \\
\text { Kunth }\end{array}$ & Dracena & Ruscaceae & 3 & 3,4 & Exótica \\
\hline AR & $\begin{array}{c}\text { Delonix regia (Bojer ex. } \\
\text { Hook.) Raf. }\end{array}$ & Flamboyant & Fabaceae & 6 & 6,7 & Exótica \\
\hline PA & $\begin{array}{c}\text { Dypsis lutescens } \mathrm{H} \text {. } \\
\text { Wendl. }\end{array}$ & $\begin{array}{c}\text { Palmeira-areca- } \\
\text { bambu }\end{array}$ & Palmaceae & 7 & 7,9 & Exótica \\
\hline$A R$ & Eugenia uniflora L. & Pitanga & Myrtaceae & 2 & 2,2 & Nativa \\
\hline$A R$ & Ficus benjamina L. & Fícus & Moraceae & 6 & 6,7 & Exótica \\
\hline$A R$ & $\begin{array}{l}\text { Juniperus chinensis } \\
\text { Linn }\end{array}$ & $\begin{array}{l}\text { Juniperus-da- } \\
\text { China }\end{array}$ & Cupressaceae & 2 & 2,2 & Exótica \\
\hline PA & $\begin{array}{l}\text { Livistona chinesis } \mathrm{R} . \\
\text { Brown ex Mart. }\end{array}$ & $\begin{array}{c}\text { Palmeira-leque- } \\
\text { de-saia }\end{array}$ & Palmaceae & 1 & 1,1 & Exótica \\
\hline$A R$ & Mangifera indica L. & Mangueira & Anacardiaceae & 5 & 5,6 & Exótica \\
\hline$A R$ & Pinus pinea L. & Pinheiro & Pinaceae & 2 & 2,2 & Exótica \\
\hline$A R$ & Pandanus veitchii Hort. & Pandanus & Pandanaceae & 1 & 1,1 & Exótica \\
\hline PA & $\begin{array}{c}\text { Phoenix roebelenii } \\
\text { O`Brien }\end{array}$ & $\begin{array}{l}\text { Palmeira-fênix ou } \\
\text { Tamareira }\end{array}$ & Palmaceae & 4 & 4,5 & Exótica \\
\hline AR & $\begin{array}{c}\text { Plinia caulifora (Mart.) } \\
\text { Kausel }\end{array}$ & Jabuticaba & Myrtaceae & 1 & 4,5 & Nativa \\
\hline AR & Plumeria rubra L. & Jasmim-manga & Apocynaceae & 2 & 2,2 & Exótica \\
\hline AR & Psidium guajava L. & Goiabeira & Myrtaceae & 3 & 3,4 & Nativa \\
\hline AR & $\begin{array}{c}\text { Schefflera actinophylla } \\
\text { Harms }\end{array}$ & Brassaia & Araliaceae & 1 & 1,1 & Exótica \\
\hline$A R$ & $\begin{array}{c}\text { Senna multijuga (Rich.) } \\
\text { Irwin et Barn. }\end{array}$ & $\begin{array}{l}\text { Aleluia ou Pau- } \\
\text { cigarra }\end{array}$ & Fabaceae & 10 & 11,2 & Nativa \\
\hline PA & $\begin{array}{c}\text { Syagrus romanzoffiana } \\
\text { Glassman }\end{array}$ & Palmeira-jerivá & Palmaceae & 12 & 13,5 & Nativa \\
\hline AR & $\begin{array}{c}\text { Tipuana tipu (Benth.) } \\
\text { O. Kuntze }\end{array}$ & Tipuana & Fabaceae & 7 & 7,9 & Nativa \\
\hline
\end{tabular}

Nota: $\mathrm{Ar}=$ espécie arbórea, $\mathrm{AB}=$ espécie arbustiva, $\mathrm{PA}=$ palmácea

\section{Análise da praça Dr. Diógenes Ribeiro de Lima}

A Praça Dr. Diógenes Ribeiro de Lima possui uma área de $10.725 \mathrm{~m}^{2}$ e é a mais arborizada do município. Segundo levantamento do arquivo público do município, o projeto de lei no 127/1954, encontrado nas Atas da Câmara Municipal, de autoria do então vereador João Augusto de São Paulo Pereira, autorizava o Prefeito Antônio Augusto Matheus a contratar a empresa Construtécnica Ltda para realizar a construção de um restaurante onde hoje funciona a Secretaria do Turismo (SETUR) nas dependências da praça Dr. Diógenes 
Ribeiro de Lima. O processo de urbanização da praça se deu ao mesmo tempo em que foi finalizada a construção do prédio em 1955. Nos jardins foram plantadas diferentes espécies de árvores e flores que fazem parte da paisagem local, sendo ainda mais valorizada pelos seus postes com luminárias que se estendem ao longo dos caminhos.

Na Praça Dr. Diógenes Ribeiro de Lima em Caraguatatuba/SP foram quantificados e avaliados vários os elementos arquitetônicos (Tabela 8).

Tabela 8. Levantamento quantitativo e qualitativo dos elementos arquitetônicos da praça Dr. Diógenes Ribeiro de Lima. Caraguatatuba/SP, 2015

Table 8. Quantitative and qualitative survey of the architectural elements of Dr. Diógenes Ribeiro de Lima square. Caraguatatuba/SP, 2015

\begin{tabular}{|c|c|c|c|}
\hline \multicolumn{4}{|c|}{ PRAÇA DR. DIÓGENES RIBEIRO DE LIMA } \\
\hline \multicolumn{4}{|c|}{ FORMA GEOMÉTRICA: ( ) QUADRANGULAR ( ) CIRCULAR ( X) RETANGULAR （） OUTRA } \\
\hline $\begin{array}{c}\text { Quantitativo } \\
\text { Equipamento/Estrutura }\end{array}$ & Quant & $\begin{array}{c}\text { Qualitativo } \\
\text { Equipamento/Estrutura }\end{array}$ & Conceito \\
\hline Bancos: quantidade & 70 & Bancos & Bom \\
\hline Iluminação: $(X)$ alta ( ) baixa & 20 & Iluminação & Bom \\
\hline Lixeiras: quantidade & 12 & Lixeiras & Ruim \\
\hline Sanitários & 02 & Sanitários & Ruim \\
\hline Telefone público & 02 & Telefone público & Regular \\
\hline Bebedouros & 00 & Bebedouros & - \\
\hline Caminhos & 08 & Piso & Ruim \\
\hline Coreto / escultura / pergolado & 00 & Tracado dos caminhos & Reqular \\
\hline Obra de arte: $(X)$ monumento ( ) estátua & 02 & Palco / coreto / esculturas & - \\
\hline Espelho d'áqua / chafariz & 00 & Pergolado & - \\
\hline Estacionamento & 00 & Monumento & Bom \\
\hline Ponto de ônibus & 01 & Espelho d'água / chafariz & - \\
\hline Ponto de taxi & 01 & Estacionamento & - \\
\hline Quadra esportiva & 00 & Ponto de ônibus & Bom \\
\hline Equipamentos de exercícios físicos & 01 & Ponto de taxi & Regular \\
\hline Estrutura para terceira idade & 01 & Quadra esportiva & - \\
\hline Equipamentos recreação infantil & 01 & Equipamentos de exercícios físicos & Ruim \\
\hline Banca de revista & 01 & Estrutura para terceira idade & Ruim \\
\hline Quiosque de alimentação ou similar & 02 & Parque infantil & Ruim \\
\hline Identificação & 02 & Banca de revista & Ruim \\
\hline Edificação institucional & 01 & Quiosque de alimentação ou similar & Regular \\
\hline Templo religioso & 00 & Vegetação & Bom \\
\hline & & Paisagismo & Regular \\
\hline & & Localização & Ótimo \\
\hline & & Conservação / limpeza & Regular \\
\hline & & Segurança & Regular \\
\hline
\end{tabular}

No local existem três diferentes modelos de bancos e que estão em bom estado de conservação, são confortáveis e possuem estrutura em concreto, sua distribuição espacial ocorre ao longo dos caminhos pavimentados e do lado externo da praça, tendo como limite as áreas ajardinadas, encontrando-se tanto em locais sombreados, como ensolarados. No total existem 70 unidades, sendo suficiente para os usuários que frequentam a praça em dias da semana e aos finais de semana (Tabela 9).

A iluminação é alta, composta por 20 postes, que estão dispostos em pontos que circulam o entorno da praça, facilitando o transito das pessoas, principalmente à noite. Há 
também 6 postes de alta tensão presentes na avenida e na rua lateral a praça e que contribuem com a iluminação

Foram observadas 12 lixeiras dispostas ao longo dos caminhos e das calçadas laterais, com bom estado de conservação, mas devido à presença de lanchonetes, doceiras, sorveterias, pipoqueiros e a feira de artesanato, o número é insuficiente para atender as necessidades dos usuários.

Existem 2 sanitários na praça, porém, encontram-se fechados e somente podem ser utilizados quando autorizados pelos funcionários da Secretaria de Turismo que funciona no interior da praça. Os telefones públicos estão em pontos extremos, o que facilita a sua utilização. O piso ao redor da praça é de pedra formando mosaicos, os caminhos são de concreto com traçados curvos, e precisam de reparos, visto que apresentam muitos pontos quebrados ou sobressalentes por causa das raízes das árvores.

Na Praça Dr. Diógenes Ribeiro de Lima não há bebedouros, palco ou coreto, obras de arte, espelho d'água ou chafariz ou quadra esportiva. Para as atividades esportivas há um espaço para a terceira idade, que está bem localizado, com vários aparelhos de ginástica de ferro e de madeira, que precisam, porém, de manutenção, por apresentarem muitas peças soltas ou quebradas.

Não há estacionamento próprio para os usuários, mas ao seu redor, visitantes da praça ou não, estacionam seus veículos. Existe um ponto de taxi e um de ônibus que atende aos moradores das regiões norte e sul, interligando o município. Os taxistas possuem um abrigo e ficam estacionados em uma das extremidades da praça.

Como equipamentos para recreação, a praça possui um parque infantil e sua estrutura é basicamente de madeira, porém, alguns brinquedos necessitam de manutenção por estarem quebrados. O parque infantil possui balança, gangorra, escorregador e gira-gira, além de ser cercado, o que facilita a observação dos pais enquanto seus filhos brincam (Figura 5).
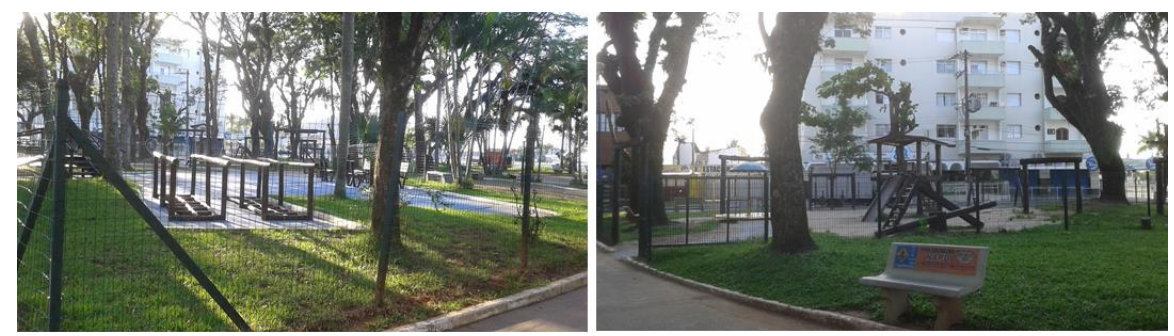

Figura 5. Equipamentos para atividades físicas e de recreação da Praça Dr. Diógenes Ribeiro da Lima. Caraguatatuba/SP, 2015

Figure 5. Equipment for physical activity and recreation of Dr. Diógenes Ribeiro da Lima Square. Caraguatatuba/SP, 2015 
Duas bancas de revistas estão localizadas na região periférica da praça, sendo uma especializada na venda de produtos religiosos e outra de jornais e revistas, ambas necessitam de melhorias, já que fazem parte da estética do loca (Figura 6).
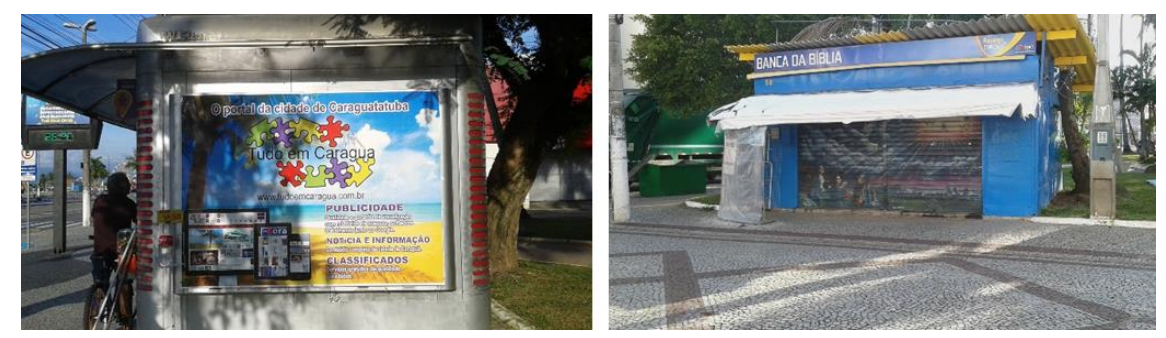

Figura 6. Bancas de jornal da Praça Dr. Diógenes Ribeiro de Lima. Caraguatatuba/SP, 2015 Figure 6. Newsstands of Dr. Diógenes Ribeiro de Lima Square. Caraguatatuba/SP, 2015

A feira de artesanato, também conhecida como "feira hippie", é tradicional na cidade, funciona diariamente na temporada e feriados, do início da tarde até a noite, quando o volume de turistas é maior. O local oferece grande diversidade de produtos, roupas, sandálias, bolsas, bijuterias, artigos de decoração e souvenires feitos com motivos litorâneos. Com o passar dos anos a quantidade de barracas cresceu, tornando-se um passeio ainda mais convidativo.

Uma questão importante é o envolvimento da população com as praças, para que esta exerça em sua totalidade os benefícios que pode gerar. Assim é importante criar opções de lazer diversificadas e interessantes o suficiente para satisfazer os anseios dos cidadãos, encorajando-os a permanecer e desfrutar destes espaços (HAQ, 2011).

Ao longo dos dias da semana, também são encontradas na praça, diversas armações e barracas dos artesãos que desenvolvem seus trabalhos nos fins de semana e feriados, prejudicando o caminhar dos usuários, chegando a ocupar quase todo o espaço disponível. Além disso, muitas dessas barracas são utilizadas como moradia de pessoas que fazem o uso da iluminação local e possuem até fogão a gás (Figura 7).
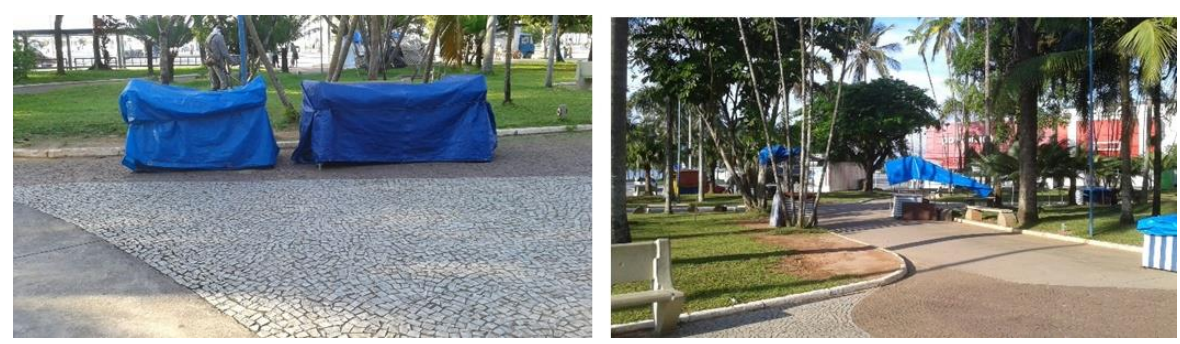

Figura 7. Armações de barracas na Praça Dr. Diógenes Ribeiro de Lima. Caraguatatuba/SP, 2015 Figure 7. Tents frames in Dr. Diógenes Ribeiro de Lima Square. Caraguatatuba/SP, 2015 
Durante os 45 dias de desenvolvimento da pesquisa de observação foram contabilizados na Praça Dr. Diógenes Ribeiro de Lima um total de 43.429 pessoas, sendo 18.962 no período matutino (422 pessoas/h ou 43,7\%) e 24.467 no vespertino (543 pessoas/h ou $56,3 \%$ ) (Tabela 9 ).

No que se refere ao tipo de atividade, pode-se observar que a praça foi mais utilizada como passagem pelos usuários, principalmente no período vespertino, num total de 18.777 pessoas (417 pessoas/h), enquanto no período da manhã transitaram 16.232 pessoas (361 pessoas/h). Já quando se contabiliza a porcentagem desta atividade nos dois períodos do dia, verifica-se que um maior número de pessoas está de passagem pela praça no período matutino $(85,5 \%)$ (Tabela 9).

Tabela 9. Total de usuários e por hora da Praça Dr. Diógenes Ribeiro de Lima nos períodos matutino e vespertino, de acordo com o tipo de atividade. Caraguatatuba/SP, 2015

Table 9. Total users and average per hour of Dr. Diógenes Ribeiro de Lima Square in the morning and afternoon periods, according to the type of activity. Caraguatatuba/SP, 2015

\begin{tabular}{|c|c|c|c|c|}
\hline Tipo de atividade & $\begin{array}{c}\text { Total } \\
\text { (45 dias) } \\
\text { Matutino } \\
\end{array}$ & $\begin{array}{c}\text { Total } \\
\text { (45 dias) } \\
\text { Vespertino }\end{array}$ & $\begin{array}{c}\text { Média } \\
\text { pessoas/hora } \\
\text { matutino }\end{array}$ & $\begin{array}{c}\text { Média } \\
\text { pessoas/hora } \\
\text { vespertino }\end{array}$ \\
\hline Lazer & 2.730 & 5.690 & $61(14,5 \%)$ & $126(23,2 \%)$ \\
\hline Passagem & 16.232 & 18.777 & $361(85,5 \%)$ & $417(76,8 \%)$ \\
\hline Geral & 18.962 & 24.467 & $422(43,7 \%)$ & $543(56,3 \%)$ \\
\hline
\end{tabular}

O indivíduo que mais transitou pela praça foi o adulto, nos dois períodos, $45,1 \%$ no matutino e $42,8 \%$ no vespertino, os quais provavelmente estavam entre a ida e a vinda do trabalho. Em termos numéricos também foi observado que, o número de pessoas nas categorias adolescente, adulto e idoso, foi semelhante nos dois períodos avaliados, fato que não ocorreu na Praça Dr. Cândido Mota (Tabela 10).

Quanto ao lazer em cada faixa etária, as crianças (15,6\%) fizeram maior uso da praça no período vespertino, os adultos $(40,9 \%)$ e os idosos $(20,7 \%)$ mais pela manhã e os adolescentes são assíduos nos dois períodos (média de 32,7\%) (Tabela 10).

Tabela 10. Usuários da Praça Dr. Diógenes Ribeiro de Lima de acordo com o tipo de atividade e período do dia. Caraguatatuba/SP, 2015

Table 10. Users of Dr. Diógenes Ribeiro de Lima Square according to the type of activity and period of the day. Caraguatatuba/SP, 2015

\begin{tabular}{lcccc}
\hline \multirow{2}{*}{ Público alvo } & \multicolumn{2}{c}{ Passagem (média pessoas/h e \%) } & \multicolumn{2}{c}{ Lazer (média pessoas/h e \%) } \\
\cline { 2 - 5 } & Matutino & Vespertino & Matutino & Vespertino \\
\hline Criança & $29(8,1 \%)$ & $44(10,5 \%)$ & $3(4,9 \%)$ & $20(15,6 \%)$ \\
Adolescente & $133(36,8 \%)$ & $152(36,4 \%)$ & $20(33,0 \%)$ & $41(32,4 \%)$ \\
Adulto & $163(45,1 \%)$ & $178(42,8 \%)$ & $25(40,9 \%)$ & $44(34,6 \%)$ \\
Idoso & $36(9,9 \%)$ & $43(10,4 \%)$ & $13(20,7 \%)$ & $22(17,8 \%)$ \\
\hline
\end{tabular}


Quanto à frequência semanal, em todos os dias da semana, o número de pessoas que passam pela praça supera o que está a lazer, nos dois períodos do dia e para todas as faixas etárias (Tabela 11). De segunda a sexta-feira, nos dois períodos do dia, a praça recebe o maior número de frequentadores, sendo a terça-feira o dia da semana com maior número de usuários no período matutino (489 pessoas/h) e no vespertino, na quinta-feira à tarde (589 pessoas/h). No domingo pela manhã e a tarde, a praça recebe o menor público (272 pessoas/h e 445 pessoas/h, respectivamente).

Em termos numéricos (Tabela 11), quanto ao lazer, as crianças e os adolescentes frequentam a praça principalmente na sexta-feira e no domingo, os adultos na sexta-feira, no sábado e no domingo e os idosos, no sábado e no domingo, todos no período vespertino. Já em termos de usuários de passagem, as crianças, os adolescentes e os idosos trafegam pela praça mais na quinta-feira e os adultos na terça-feira, todos no período vespertino. Durante os dias de semana, nota-se também um grande número de adultos no período matutino que estão de passagem pela praça, fato que não ocorreu com as outras faixas etárias.

Tabela 11. Usuários por hora em cada dia da semana de acordo com a atividade (lazer ou passagem) e período do dia (matutino e vespertino) na Praça Dr. Diógenes Ribeiro de Lima.

Caraguatatuba/SP, 2015

Table 11. Users per hour in each day of the week according to the activity (recreation or passage) and period of the day (morning and afternoon) in Dr. Diógenes Ribeiro de Lima Square. Caraguatatuba/SP, 2015

\begin{tabular}{|c|c|c|c|c|c|c|c|c|c|c|c|c|c|c|c|c|c|c|}
\hline & \multicolumn{4}{|c|}{ Criança } & \multicolumn{4}{|c|}{ Adolescente } & \multicolumn{4}{|c|}{ Adulto } & \multicolumn{4}{|c|}{ Idoso } & \multicolumn{2}{|c|}{ Total } \\
\hline & \multicolumn{2}{|c|}{$\mathrm{M}$} & \multicolumn{2}{|c|}{ V } & \multicolumn{2}{|c|}{$\mathrm{M}$} & \multicolumn{2}{|c|}{$\mathrm{V}$} & \multicolumn{2}{|c|}{$\mathrm{M}$} & \multicolumn{2}{|c|}{ V } & \multicolumn{2}{|c|}{$\mathrm{M}$} & \multicolumn{2}{|c|}{ V } & \multirow{2}{*}{$M$} & \multirow{2}{*}{ V } \\
\hline & $\mathrm{L}$ & $\mathrm{P}$ & $\mathrm{L}$ & $\mathrm{P}$ & $\mathrm{L}$ & $\mathrm{P}$ & $\mathrm{L}$ & $\mathrm{P}$ & $\mathrm{L}$ & $\mathrm{P}$ & $\mathrm{L}$ & $\mathrm{P}$ & $\mathrm{L}$ & $\mathrm{P}$ & $\mathrm{L}$ & $\mathrm{P}$ & & \\
\hline D & 3 & 20 & 23 & 34 & 15 & 66 & 45 & 109 & 23 & 102 & 56 & 117 & 12 & 33 & 28 & 33 & 272 & 445 \\
\hline $2^{\underline{a}}$ & 2 & 29 & 17 & 43 & 16 & 145 & 39 & 155 & 21 & 170 & 31 & 190 & 9 & 39 & 17 & 48 & 430 & 539 \\
\hline $3^{\mathrm{a}}$ & 2 & 35 & 15 & 45 & 22 & 161 & 34 & 171 & 26 & 189 & 30 & 205 & 14 & 40 & 20 & 44 & 489 & 564 \\
\hline $4^{\underline{a}}$ & 2 & 29 & 16 & 44 & 19 & 158 & 34 & 160 & 22 & 172 & 37 & 188 & 10 & 32 & 17 & 45 & 445 & 540 \\
\hline $5^{\mathrm{a}}$ & 4 & 38 & 21 & 50 & 25 & 154 & 38 & 178 & 31 & 175 & 35 & 196 & 16 & 37 & 22 & 49 & 482 & 589 \\
\hline $6^{\mathrm{a}}$ & 4 & 31 & 25 & 46 & 22 & 130 & 53 & 139 & 24 & 172 & 56 & 168 & 11 & 33 & 20 & 37 & 428 & 543 \\
\hline $\mathrm{S}$ & 4 & 18 & 21 & 40 & 19 & 89 & 42 & 118 & 25 & 125 & 63 & 151 & 15 & 31 & 31 & 42 & 326 & 507 \\
\hline
\end{tabular}

$\mathrm{M}=$ matutino, $\mathrm{V}=$ vespertino, $\mathrm{L}=$ lazer e $\mathrm{P}=$ passagem

Quanto à porcentagem em cada categoria de usuários e em cada dia da semana, do total de pessoas que frequentam a praça no domingo pela manhã em atividade de lazer existem $1 \%$ de crianças, $6 \%$ de adolescentes, $8 \%$ de adultos e $4 \%$ de idosos, já no período vespertino são $5 \%$ de crianças, $10 \%$ de adolescentes, $13 \%$ de adultos e $6 \%$ de idosos. No sábado pela manhã são $1 \%$ de crianças, $6 \%$ de adolescentes, $8 \%$ de adultos e $5 \%$ de idosos e a tarde, $4 \%$ de crianças, $8 \%$ de adolescentes, $12 \%$ de adultos e $6 \%$ de idosos (Tabela 12 ). 
Tabela 12. Porcentagem de usuários por hora em cada dia da semana de acordo com a atividade (lazer ou passagem) na Praça Dr. Diógenes Ribeiro de Lima. Caraguatatuba/SP, 2015

Table 12. Percentage of users per hour in each day of the week according to the activity (recreation or passage) in Dr. Diógenes Ribeiro de Lima Square. Caraguatatuba/SP, 2015

\begin{tabular}{|c|c|c|c|c|c|c|c|c|c|c|c|c|c|c|c|c|c|c|}
\hline & \multicolumn{4}{|c|}{ Criança \% } & \multicolumn{4}{|c|}{ Adolescente \% } & \multicolumn{4}{|c|}{ Adulto $\%$} & \multicolumn{4}{|c|}{ Idoso \% } & \multicolumn{2}{|c|}{ Total \% } \\
\hline & \multicolumn{2}{|c|}{$\mathrm{M}$} & \multicolumn{2}{|c|}{$\mathrm{V}$} & \multicolumn{2}{|c|}{$\mathrm{M}$} & \multicolumn{2}{|c|}{$\mathrm{V}$} & \multicolumn{2}{|c|}{$\mathrm{M}$} & \multicolumn{2}{|c|}{$\mathrm{V}$} & \multicolumn{2}{|c|}{$\mathrm{M}$} & \multicolumn{2}{|c|}{ V } & \multirow{2}{*}{ L } & \multirow{2}{*}{$\mathrm{P}$} \\
\hline & $\mathrm{L}$ & $P$ & $\mathrm{~L}$ & $P$ & $\mathrm{~L}$ & $P$ & $\mathrm{~L}$ & $P$ & $\mathrm{~L}$ & $P$ & $\mathrm{~L}$ & $P$ & $\mathrm{~L}$ & $\mathrm{P}$ & $\mathrm{L}$ & $P$ & & \\
\hline D & 1 & 7 & 5 & 8 & 6 & 24 & 10 & 24 & 8 & 37 & 13 & 26 & 4 & 12 & 6 & 7 & 27 & 73 \\
\hline $2^{\mathrm{a}}$ & 0 & 7 & 3 & 8 & 4 & 34 & 7 & 29 & 5 & 40 & 6 & 35 & 2 & 9 & 3 & 9 & 15 & 85 \\
\hline $3^{\mathrm{a}}$ & 0 & 7 & 3 & 8 & 5 & 33 & 6 & 30 & 5 & 39 & 5 & 36 & 3 & 8 & 4 & 8 & 15 & 85 \\
\hline $4^{\mathrm{a}}$ & 0 & 7 & 3 & 8 & 4 & 35 & 6 & 30 & 5 & 39 & 7 & 35 & 2 & 7 & 3 & 8 & 16 & 84 \\
\hline $5^{\mathrm{a}}$ & 1 & 8 & 4 & 8 & 5 & 32 & 6 & 30 & 6 & 36 & 6 & 33 & 3 & 8 & 4 & 8 & 18 & 82 \\
\hline $6^{a}$ & 1 & 7 & 5 & 8 & 5 & 30 & 10 & 26 & 6 & 40 & 10 & 31 & 3 & 8 & 4 & 7 & 21 & 79 \\
\hline $\mathrm{S}$ & 1 & 5 & 4 & 8 & 6 & 27 & 8 & 23 & 8 & 38 & 12 & 30 & 5 & 10 & 6 & 8 & 25 & 75 \\
\hline
\end{tabular}

$\mathrm{M}=$ matutino, $\mathrm{V}=$ vespertino, $\mathrm{L}=$ lazer e $\mathrm{P}=$ passagem

Da mesma forma que na praça Dr. Cândido Mota, o número de usuários que transitam pela praça Dr. Diógenes Ribeiro de Lima é bem maior do que os que a utilizam para lazer, sendo que este porcentual aumenta de forma linear do início da semana (segundafeira) até no domingo, quando o maior público é encontrado, quase chegando a dobrar (Figura 8).

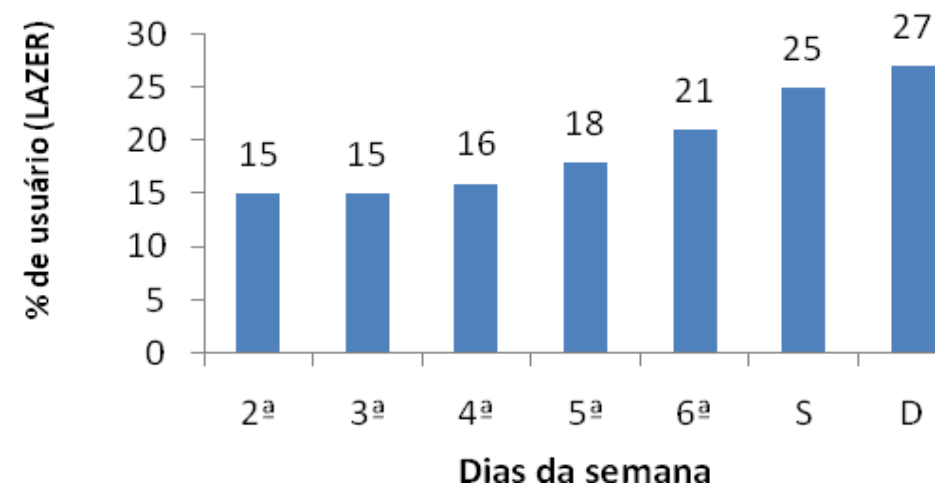

Figura 8. Usuários em atividade de lazer (\%) em cada dia da semana na Praça Dr. Diógenes Ribeiro de Lima. Caraguatatuba/SP, 2015

Figure 8. Users in leisure activity (\%) in each weekday at Dr. Diógenes Ribeiro de Lima Square.

Caraguatatuba/SP, 2015

No levantamento das espécies vegetais arbóreas presentes na Praça Dr. Diógenes Ribeiro de Lima foram encontradas 30 espécies com mais de $2 \mathrm{~m}$ de altura, totalizando 242 plantas, sendo 103 palmáceas, 127 arbóreas e 12 arbustivas. As espécies exóticas foram predominantes $(66,9 \%)$, sendo a Cyca circinalis Roxb., conhecida como palmeira-sagu, a mais encontrada com 39 exemplares ou 16,1\% (Tabela 13). Em levantamento realizado em 32 praças de Curitiba/PR, Viezzer (2014) relatou que 56,7\% das espécies presentes eram exóticas, pouco contribuindo para a conservação da biodiversidade da região. 
Tabela 13. Espécies vegetais na Praça Dr. Diógenes Ribeiro de Lima. Caraguatatuba, 2015 Table 13. Plants species in Square Dr. Diógenes Ribeiro de Lima. Caraguatatuba, 2015

\begin{tabular}{|c|c|c|c|c|c|c|}
\hline Grupo & Nome científico & Nome comum & Família & Quant. & $\begin{array}{c}\text { Frequência } \\
\%\end{array}$ & Espécie \\
\hline AR & Anadenanthera colubrina & Angico-branco & Fabaceae & 2 & 0,8 & Nativa \\
\hline$A R$ & Anadenanthera peregrina & Angico-vermelho & Fabaceae & 8 & 3,3 & Nativa \\
\hline PA & $\begin{array}{l}\text { Archontophoenix } \\
\text { cunninghamiana }\end{array}$ & Palmeira-seafórtia & Palmaceae & 4 & 1,7 & Exótica \\
\hline PA & Attalea oleifera & Indaiá & Palmaceae & 3 & 1,2 & Nativa \\
\hline$A R$ & Bauhinia blakeana Dunn & Pata-de-vaca & Fabaceae & 6 & 2,5 & Exótica \\
\hline$A B$ & Bougainvillea glabra & Primavera & Nyctaginaceae & 3 & 1,2 & Nativa \\
\hline PA & Caryota mitis Lour. & $\begin{array}{l}\text { Palmeira-rabo-de- } \\
\text { peixe }\end{array}$ & Palmaceae & 4 & 1,7 & Exótica \\
\hline $\mathrm{PA}$ & Cocos nucifera & Coco-da-baía & Palmaceae & 25 & 10,3 & Exótica \\
\hline$A B$ & Cordyline terminalis & Dracena & Ruscaceae & 8 & 3,3 & Exótica \\
\hline CY & Cyca circinalis Roxb. & Palmeira-sagu & Cycadaceae & 39 & 16,1 & Exótica \\
\hline AR & Delonix regia & Flamboyant & Fabaceae & 5 & 2,1 & Exótica \\
\hline $\mathrm{PA}$ & Dypsis lutescens & Areca-bambu & Palmaceae & 25 & 10,3 & Exótica \\
\hline AR & Eugenia uniflora & Pitanga & Myrtaceae & 1 & 0,4 & Nativa \\
\hline AR & Ficus benjamina & Fícus & Moraceae & 9 & 3,7 & Exótica \\
\hline$A R$ & $\begin{array}{l}\text { Handroanthus heptaphyllus } \\
\text { (Vell.) Mattos }\end{array}$ & Ipê-rosa & Bignoniaceae & 1 & 0,4 & Nativa \\
\hline$A B$ & Hibiscus rosa-sinensis Linn & Mimo ou Hibisco & Malvaceae & 1 & 0,4 & Exótica \\
\hline PA & Livistona chinesis & $\begin{array}{l}\text { Palmeira-leque-de- } \\
\text { saia }\end{array}$ & Palmaceae & 14 & 5,8 & Exótica \\
\hline AR & Mangifera indica & Mangueira & Anacardiaceae & 2 & 0,8 & Exótica \\
\hline AR & Pinus pinea & Pinheiro & Pinaceae & 3 & 1,2 & Nativa \\
\hline AR & Plinia caulifora & Jabuticaba & Myrtaceae & 1 & 0,4 & Nativa \\
\hline$A R$ & Plumeria rubra & Jasmim-manga & Apocynaceae & 3 & 1,2 & Exótica \\
\hline$A R$ & Psidium guajava & Goiabeira & Myrtaceae & 1 & 0,4 & Nativa \\
\hline PA & $\begin{array}{c}\text { Roystonea oleracea O. F. } \\
\text { Cook }\end{array}$ & Palmeira-imperial & Palmaceae & 10 & 4,1 & Exótica \\
\hline AR & Schefflera actinophylla & Brassaia & Araliaceae & 2 & 0,8 & Exótica \\
\hline AR & Senna multijuga & $\begin{array}{l}\text { Aleluia ou Pau- } \\
\text { cigarra }\end{array}$ & Fabaceae & 2 & 0,8 & Nativa \\
\hline $\mathrm{PA}$ & Syagrus romanzoffiana & Palmeira-jerivá & Palmaceae & 14 & 5,8 & Nativa \\
\hline AR & Terminalia catappa L. & Chapéu-de-sol & Combretaceae & 5 & 2,1 & Exótica \\
\hline AR & Tibouchina granulosa Cogn. & Quaresmeira & Melastomataceae & 1 & 0,4 & Nativa \\
\hline AR & Tipuana tipu & Tipuana & Fabaceae & 18 & 7,4 & Nativa \\
\hline PA & Wodyetia bifurcata Irvine & $\begin{array}{l}\text { Palmeira-rabo-de- } \\
\text { raposa }\end{array}$ & Palmaceae & 22 & 9,1 & Nativa \\
\hline
\end{tabular}

Nota: Quant $=$ quantidade, $A R=$ espécie arbórea, $A B=$ espécie arbustiva, $P A=$ palmácea $C Y=$ cicadácea

\section{CONCLUSÕES}

Com o levantamento histórico das praças Dr. Cândido Mota e Dr. Diógenes Ribeiro de Lima, conclui-se que ambas são importantes para os cidadãos caraguatatubenses, sendo que a primeira abriga diversos patrimônios da cidade desde a sua fundação. Com a análise quali-quantitativa dos elementos arquitetônicos, conclui-se que a praça Dr. Diógenes Ribeiro de Lima oferece maiores opções para a prática de exercícios físicos e recreação infantil do que a praça Dr. Cândido Mota, que por sua vez, é mais utilizada para eventos musicais e culturais. Quanto à avaliação das estruturas físicas, ambas apresentam qualidade regular, necessitando de manutenção e reparos. 
Com a caracterização dos usuários, conclui-se que as praças Dr. Cândido Mota e Dr. Diógenes Ribeiro de Lima tem a função de promover o lazer a diferentes grupos de pessoas, principalmente aos finais de semana. Em ambas, o maior movimento é de pessoas em passagem no período vespertino, que em sua maioria são adultos de 21 a 60 anos. Por sua vez, os adolescentes frequentam mais a praça Dr. Diógenes Ribeiro de Lima e os idosos, a Dr. Cândido Mota.

\section{REFERÊNCIAS}

CARAGUATATUBA. Lei oㅜ 1344, de 13 de dezembro de 2006. Declara bens municipais como pertencentes ao patrimônio histórico e cultural de Caraguatatuba. Disponível em: <http://www.legislacaoonline.com.br/caraguatatuba/images/leis/html/L13442006.html>.

Acesso em: 08 mar. 2015.

COSTA, S. K.; SILVA JUNIOR, M. F. da; RANGEL, M. C. O processo de intervenção em espaços públicos urbanos dos usuários: praças públicas. Revista Eletrônica do PRODEMA, Fortaleza, v. 4, n. 1, p. 25-35, 2010.

DE ANGELIS, B. L. D.; CASTRO, R. M. de; DE ANGELIS NETO, G. Metodologia para levantamento, cadastramento, diagnóstico e avaliação de praças no Brasil. Engenharia Civil, Guimarães, Portugal, v. 4, n. 1, p. 57-70, 2004.

DE ANGELIS, B. L. D.; DE ANGELIS NETO, G.; MOTA, C. R.; SCAPIN, C. R.; MANO, L. R.; SCHIAVON, V. S.; HOFFMANN, A. C.; SAVI, E.; SILVA, G. F. F.; RECCO, L. H.; BARCOS, M.; SANTANA, M.; FANTINI, P. R.; DOMINGUES, R.; BARBEIRO, T. L.; YUASSA, V. N. Avaliação das Praças de Maringá, Estado do Paraná, Brasil. Acta Scientiarum, Maringá, v. 27, n. 4, p. 629-638, 2005.

DEMATTÊ, M. E. S. P. Princípios de paisagismo. Jaboticabal: FUNEP, 1999, 101 p.

DOURADO, L. A. C.; SILVA, E. A. Espacialização e ordenamento das Praças, espaços de recreação e lazer, na Estância Turística llha Solteira/SP. Revista Eletrônica da Associação dos Geógrafos Brasileiros, Três Lagoas, v. 2, n. 2, p. 67-86, 2005.

GOOGLE EARTH. Mapas. Disponível em: <http://google.com/earth>. Acesso em: 02. Fev. 2015.

GOMES, M. A. S.; SILVA, R. N.; SILVA, J. C. S.; SILVA, T. G. F. Caracterização e Análise dos Espaços Públicos da Cidade de Arapiraca/AL. Revista Ateliê Geográfico, Goiânia, v. 6, n. 4, p. 137-157, 2012.

HAQ, S. M. Urban Green Spaces and an Integrative Approach to Sustainable Environment. Journal of Environmental Protection, Delaware, USA, v. 2, n. 5, p. 601-608, 2011.

INSTITUTO BRASILEIRO DE GEOGRAFIA E ESTATÍSTICA (IBGE). Estimativas populacionais para os municípios brasileiros em 01.07.2014 Disponível em: <http://ftp.ibge.gov.br/Estimativas_de_Populacao/Estimativas_2014/estimativa_dou_2014.pdf >. Acesso em: 28 fev. 2015. 
LOBODA, C. R.; DE ANGELIS, B. L. D. Áreas verdes públicas urbanas: conceitos, usos e funções. Ambiência, Guarapuava, v. 1, n. 1, p. 125-139, 2009.

ROLIM, G. de S.; CAMARGO, M. B. P. de; LANIA, D. G.; MORAES, J. F. P. de. Classificação climática de Köppen e de Thornthwaite e sua aplicabilidade na determinação de zonas agroclimáticas para o estado de São Paulo. Bragantia, Campinas, v. 66, n. 4, p. 711-720, 2007.

SOUZA, M. C. da C.; AMORIM, M. C. de C. T. A problemática ambiental e o verde urbano. Periódico Técnico e Científico Cidades Verdes, v. 1, n. 1, p. 29-43, 2013.

VIEZZER, J. As linhas projetuais paisagísticas e a percepção dos usuários das praças de Curitiba-PR, Curitiba, 2014. 123 f. Dissertação (Mestrado em Engenharia Florestal), Universidade Federal do Paraná. 